\title{
Economic and environmental effects of providing increased amounts of solid feed to veal calves
}

\author{
H. Mollenhorst, ${ }^{\star} \dagger^{1,2}$ P. B. M. Berentsen, $\dagger$ H. Berends, $\ddagger^{3}$ W. J. J. Gerrits, $\ddagger$ and I. J. M. de Boer* \\ ${ }^{*}$ Animal Production Systems group, Wageningen University, PO Box 338, $6700 \mathrm{AH}$ Wageningen, the Netherlands \\ †Business Economics group, Wageningen University, PO Box 8130, 6700 EW Wageningen, the Netherlands \\ $\ddagger$ Animal Nutrition group, Wageningen University, PO Box 338, $6700 \mathrm{AH}$, Wageningen, the Netherlands
}

\section{ABSTRACT}

Traditionally, veal calves receive most of their nutrients from milk replacer (MR). Nowadays, however, solid feed (SF; i.e., concentrates and roughages) increasingly substitutes for MR. Studies have shown that providing $\mathrm{SF}$ reduces different types of nonnutritive oral behaviors. The objective of this study was to assess the economic and environmental effects of substituting SF for $\mathrm{MR}$ in veal calf diets. With respect to environmental effects, we considered the emission of greenhouse gases and land occupation. Substitution rates were based on an experiment in which 160 calves were provided 2 mixtures of SF at 4 levels of dry matter (DM) intake. Mixtures of SF contained either $80 \%$ concentrates, $10 \%$ corn silage, and $10 \%$ straw on DM basis (C80) or $50 \%$ concentrates, $25 \%$ corn silage, and 25\% straw (C50). The 4 levels of SF during the last $17 \mathrm{wk}$ of the fattening period were 20, 100, 180, and $260 \mathrm{~kg}$ of DM SF. Additionally, provision of MR was adjusted to achieve equal rates of carcass gain. Substitution rates, representing the $\mathrm{SF}$ equivalent needed to substitute for $1 \mathrm{~kg}$ of $\mathrm{DM}$ $\mathrm{MR}$, were $1.43 \mathrm{~kg}$ of DM for C80 and $1.61 \mathrm{~kg}$ of DM for C50. Economic effects were assessed based on prices and substitution rates of SF for MR and the possible penalty for carcass color. Environmental effects were assessed based on effects related to the production of feed ingredients, substitution rates, and changes in enteric methane emission and energy use for feed preparation. Costs of feeding SF needed to substitute for $1 \mathrm{~kg}$ of DM MR were $€ 0.68$ lower for $\mathrm{C} 80$ and $€ 0.71$ lower for C50, compared with the costs of feeding $1 \mathrm{~kg}$ of DM MR. When carcass color scores became too high, however, lower feeding costs were offset by lower revenues

\footnotetext{
Received December 9, 2014.

Accepted November 25, 2015.

${ }^{1}$ Corresponding author: mollenhorst@qlip.nl

${ }^{2}$ Current address: Qlip BV, PO Box 119, 7200 AC, Zutphen, the Netherlands.

${ }^{3}$ Current address: Trouw Nutrition Ruminant Research Centre, PO Box 220, 5830 AE Boxmeer, the Netherlands.
}

from meat. Emissions of greenhouse gases were hardly affected when SF intake was increased. In general, increased enteric methane emission were offset by lower emissions from feed production and energy use. Land occupation increased when intake of SF was increased, mostly because of the high land occupation associated with some concentrate ingredients. In conclusion, this study only showed a negative effect on land occupation when substituting SF for part of the MR in diets of veal calves. Effects on costs and greenhouse gas emissions were neutral or positive.

Key words: life cycle assessment, greenhouse gas emission, partial budgeting, concentrate, straw

\section{INTRODUCTION}

Traditionally, veal calves receive most of their nutrients from milk replacer (MR). Nowadays, however, increasing amounts of solid feed (SF; i.e., concentrates and roughages) are provided, partly because it is enforced by European Union (EU) legislation (97/182/ EG) and partly because of increasing prices of MR ingredients. This increase in price is caused primarily by almost a doubling of the price for whey powder during the last decade (LEI, 2014) and by similar trends for other ingredients derived from milk. Studies have shown that good quality veal could be produced with similar rates of carcass gain, while providing amounts of SF well above EU requirements (Cozzi et al., 2002; Prevedello et al., 2012; Brscic et al., 2014). Furthermore, MR could be lowered linearly with increasing $\mathrm{SF}$, whereas rate of carcass gain remained unchanged (Berends et al., 2014). Levels of SF during the final 17 wk of the fattening period increased from minimal EU legislation level (20 $\mathrm{kg}$ of $\mathrm{DM})$ to a level close to ad libitum intake $(250 \mathrm{~kg}$ of DM). Ad libitum intake of $\mathrm{SF}$ was determined in an experiment in which calves were provided free access to MR and different types of SF (Webb et al., 2014). The experiment of Berends et al. (2014) was unique for 2 reasons: their aim was to attain equal rates of carcass gain, and not to measure the effect of a pre-defined ration, and they provided 2 
mixtures of SF at 4 levels of intake. The mixtures of SF differed only in the ratio of roughage to concentrate. Their experimental protocol enabled calculation of the substitution value for carcass gain of SF relative to MR (in short, substitution rate) at 2 ratios of roughage to concentrate. They showed no effect of level of SF intake on substitution rate.

Studies on calf well-being showed that providing SF, and especially roughage, reduces different types of nonnutritive oral behaviors (Veissier et al., 1998; Webb et al., 2012; Leruste et al., 2014), which are a concern in veal production (Cozzi et al., 2009). Effects of SF on rumen and abomasal health depend on the amount and composition of the SF (Mattiello et al., 2002; Suárez et al., 2007; Berends et al., 2014). Stimulating rumen development in early stages could contribute to improved performance toward the end of the fattening period, especially when high levels of SF are provided (Berends et al., 2012b; Xie et al., 2013). In addition to animal health and well-being, other sustainability issues have to be assessed before feeding strategies with higher levels of SF can be implemented successfully.

It is important for farmers to know if a new strategy is profitable. Economic potential of substituting SF for MR depends on prices and substitution rates, and if meat can be sold at the same price, because providing more SF might change meat characteristics, especially color. The recent increase of prices of MR ingredients re-enforces the idea that substituting SF for MR could be profitable. About $65 \%$ of total variable costs are feeding costs (KWIN-V, 2013), so a small difference in relative prices and substitution rate can have a substantial effect on profitability. In addition to MR, feeding $140 \mathrm{~kg}$ of DM SF in $201 \mathrm{~d}$ did not affect carcass color and was profitable (Brscic et al., 2014). For higher levels of SF, however, carcass color might change and cost reductions must be large enough to compensate for a reduced meat price, if the color score becomes too high, indicating darker colored meat.

Current livestock production contributes to some environmental concerns, because it is the largest anthropogenic user of land and produces a major share of anthropogenic greenhouse gas (GHG) emissions (Steinfeld et al., 2006; Gerber et al., 2013). The environmental effect of substituting SF for MR depends primarily on effects related not only to the production of the feeds and their ingredients, but also to their substitution rates. Additionally, there needs to be an accounting of emissions from animals, manure, and combustion of energy sources on the veal farm. Two environmental effects were expected to change considerably: emissions of GHG and land occupation. Expected changes in GHG emissions and land occupation have 4 causes: production of feed ingredients, enteric $\mathrm{CH}_{4}$ emission, water heating, and manure composition. Production of feed is an important contributor to the environmental effect of animal products, and GHG emissions and land occupation differ among feed ingredients (Van Middelaar et al., 2013). Enteric $\mathrm{CH}_{4}$ emission will increase when diets contain more SF (e.g., Beauchemin and McGinn, 2005; Van Middelaar et al., 2013). If veal calves receive only MR, they will not develop a fully functional rumen (Flatt et al., 1958; Church, 1988; Suárez et al., 2006) and enteric fermentation will be negligible (van den Borne et al., 2006; Labussiere et al., 2009). As diets of veal calves contain more $\mathrm{SF}$, their rumen will develop fully, with accompanying increased $\mathrm{CH}_{4}$ production. Providing more SF will reduce energy required to heat water for $\mathrm{MR}$, and consequently reduce $\mathrm{CO}_{2}$ emissions. Changing feed composition affects manure composition, and related $\mathrm{N}_{2} \mathrm{O}$ and $\mathrm{CH}_{4}$ emissions. Whether or not all these changes result in a net positive or negative effect on environmental impact is still unclear.

Because economic and environmental consequences are not yet clear, it is necessary to assess whether providing higher levels of SF is economically profitable and environmentally sound. The objective of this study, therefore, was to assess the economic and environmental effects of substituting SF for MR in veal calf diets, while maintaining equal rates of carcass gain.

\section{MATERIALS AND METHODS}

\section{Substitution Rates}

Substitution rates were based on Berends et al. (2014). In their experiment with 160 calves, 2 mixtures of SF were provided at 4 levels of DMI in a $2 \times 4$ factorial arrangement, with 4 pens per treatment combination and pen as the experimental unit. Mixtures of SF contained either $80 \%$ concentrates, $10 \%$ corn silage, and $10 \%$ straw on DM basis (C80) or $50 \%$ concentrates, $25 \%$ corn silage, and $25 \%$ straw (C50). The 4 levels of SF during the last $17 \mathrm{wk}$ of the fattening period were 20 , 100,180 , and $260 \mathrm{~kg}$ of DM SF, which afterward was determined to be 7 to $62 \%$ of total DMI. Additionally, MR was provided and adjusted throughout the study to achieve equal rates of carcass gain on all diets. Analysis of covariance was used to estimate the reduction of MR intake per unit of SF intake for the 2 mixtures of SF (Berends et al., 2014). The goal of equal rates of carcass gain was not fully reached, so regression coefficients were estimated while correcting for difference in rate of carcass gain by expressing MR intake per kilogram of carcass gain (Berends et al., 2014). Substitution rates were achieved for C80 and C50 by multiplying the estimated regression coefficients by the average carcass gain $(81 \mathrm{~kg})$ during the experimental period and then 
taking the inverse. Substitution rates represent the SF equivalent needed to substitute for $1 \mathrm{~kg}$ of $\mathrm{DM} \mathrm{MR}$, while maintaining an equal rate of carcass gain and were $1.43 \mathrm{~kg}$ of DM SF per $\mathrm{kg}$ of DM MR for C80 and $1.61 \mathrm{~kg}$ of DM SF per $\mathrm{kg}$ of DM MR for C50.

\section{Economic Effects}

Economic effects were evaluated with partial budgeting, which is an economic method that assesses effects of a change from the current to a new scenario (Kay et al., 2011). Four economic categories (i.e., additional and reduced costs, and additional and reduced revenues) were taken into account to calculate the net change in profit from a change in scenario, in this case substituting either $1.43 \mathrm{~kg}$ of DM C80 or $1.61 \mathrm{~kg}$ of DM C50 for $1 \mathrm{~kg}$ of MR. Prices of MR, concentrates, corn silage, and straw, and of on-farm energy use for heating water for MR were based on Dutch standards for veal production (KWIN-V, 2013).

Substituting SF for MR led to an increase of the carcass color score indicating darker meat color (Berends et al., 2014). Carcass color was assessed on the rectus abdominis muscle of the carcass, using a handheld spectrophotometer and scoring from 1 (pale) to 15 (red). Scores $\leq 10$ were considered white veal, whereas scores $\geq 11$ were considered rosé veal, which is marketed at a lower price. Within the range of color scores for white veal, however, prices are reduced gradually with increasing color scores as well. A herd with an average color score $\leq 4.8$ receives the highest price per kilogram of carcass weight. For each 0.1-unit increase in color score, the price per kilogram is reduced by $€ 0.05$ (Wiebe Mulder, VanDrie group, Mijdrecht, the Netherlands, personal communication). Based on a final carcass weight of $142 \mathrm{~kg}$ (KWIN-V, 2013), every 0.1 increase in color score above 4.8 results in a loss of $€ 7.10$ ( $=€ 0.05 / \mathrm{kg} \times 142 \mathrm{~kg}$ ) per calf. Based on linear regression on data from Berends et al. (2014), the color score increased 0.010 when SF substituted for $1 \mathrm{~kg}$ of DM MR (95\% CI: 0.003 to 0.017 ; df $=30$ ), with no difference between C50 and C80. This resulted in a loss of $€ 0.71(=0.010 / 0.1 \times € 7.10)$ when SF substituted for $1 \mathrm{~kg}$ of DM MR.

\section{Environmental Effects}

Life cycle assessment (LCA), which is an internationally accepted and standardized method to assess the environmental effects of entire production chains (Guinée et al., 2002; Baumann and Tillman, 2004), was used to evaluate environmental effects with respect to emissions of GHG and land occupation. Life cycle assessment is also used commonly to evaluate animal production systems (De Vries and De Boer, 2010). Effects of increased or decreased use of feed ingredients, increased enteric fermentation, and decreased energy use for water heating were considered (Figure 1). Emissions from manure were not considered, however, because with the available emission factors (Oenema et al., 2000; Van der Hoek, 2002; IPCC, 2006), no distinction could be made between emissions from manure of veal calves fed different rations. Important GHG related to animal production are $\mathrm{CO}_{2}, \mathrm{CH}_{4}$, and $\mathrm{N}_{2} \mathrm{O}$ (Gerber et al., 2013). They were summed by their equivalence factor in terms of $\mathrm{CO}_{2}$-equivalents $\left(\mathbf{C O}_{2}\right.$-eq; 100 -yr time horizon): 1 for $\mathrm{CO}_{2}, 25$ for $\mathrm{CH}_{4}$, and 298 for $\mathrm{N}_{2} \mathrm{O}$ (Forster et al., 2007). With respect to land occupation, only changes in agricultural land related to feed ingredients were considered.

The composition of $\mathrm{MR}$ and concentrates were known (Berends et al., 2014). The composition of MR used in the LCA was adapted to reduce the number of ingredients. Ingredients present at rates below $2 \%$ were excluded; other ingredients were increased proportionally (Table 1). Ingredients were divided into main products (Appendix Table A1) and by-products (Appendix Table A2), because environmental effects of

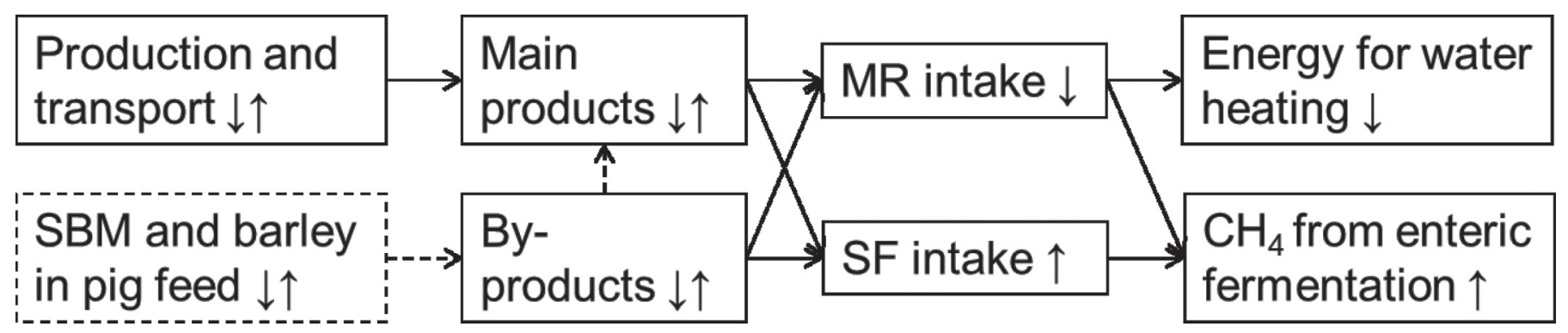

Figure 1. Changes in environmental effects due to substituting solid feed (SF; concentrates and roughages) for milk replacer (MR). Ingredients of both MR and SF could be main products and by-products, with their respective environmental effects. Solid arrows represent effects on direct effects or product flows, whereas dotted arrows represent effects of the alternative application of by-products [in this case, energy and protein in pig feed from soybean meal (SBM) and barley]. 
main products and by-products are assessed differently. A production process can result in only one product (the main product) or it can result in a main product and a by-product. When corn silage is the main product, for example, then no by-product is present. When palm oil is the main product, however, then palm kernel expeller is the by-product. Effects of by-products were assessed by system expansion, which means that the effect allocated to a by-product was determined by its alternative application (Van Zanten et al., 2014). The effect of the products needed to replace the by-product in its alternative application is the effect allocated to the by-product (Figure 1). For each by-product, we assumed that the alternative application was pig feed and that soybean meal and barley would be replaced proportionately, based on their digestible protein and net energy contents (Weidema, 2003; Dalgaard et al., 2008; Appendix Tables A2 and A3). Effects of production and transport of main products were based on yield and effect data (before allocation) from Vellinga et al. (2013). Where necessary, effect data for main products were corrected for the effect, following system expansion, allocated to the by-products (dotted arrow between by-products and main products in Figure 1). Because of a lack of data needed for system expansion, economic allocation was used for coconut oil, pregelatinized wheat starch, and soy protein concentrate (Appendix Table A1). Effects of the processing of MR and concentrates at the feed mill were based on Vellinga et al. (2013).

Enteric $\mathrm{CH}_{4}$ emission was calculated from gross energy (GE) content of the feed (Table 1) and emission factors per feed type. Based on experimental data with veal calves in respiration chambers one emission factor for $\mathrm{SF}(5.5 \%$ of $\mathrm{GE})$ and one for MR $(0.3 \%$ of $\mathrm{GE})$ was derived (van den Borne et al., 2006; Labussiere et al., 2009; Berends et al., 2012a, and unpublished data of J. J. G. C. van den Borne, Wageningen University, Wageningen, the Netherlands, personal communication). To distinguish between MR, concentrates, and roughages, however, we had to develop a new set of emission factors. As best estimates for the different diet components, we used the specific factor mentioned above for MR (0.3\%), the IPCC (2006) value for feedlot cattle fed diets with $90 \%$ or more concentrates for concentrates (3.0\%), and the IPCC (2006) value for other cattle for roughages $(6.5 \%)$. In a sensitivity analysis, the influence on the final conclusions of distinguishing only between MR (0.3\%) and SF (5.5\%) was tested.

Emissions of GHG from heating water for MR were calculated as gas use of $0.0578 \mathrm{~m}^{3}$ per $\mathrm{kg}$ MR (KWIN$\mathrm{V}, 2013)$, a heating value of $39 \mathrm{MJ} / \mathrm{m}^{3}$ gas, and an emission value of $0.0594 \mathrm{~kg}$ of $\mathrm{CO}_{2}$-eq per MJ of gas (Weidema et al., 2013).

\section{RESULTS}

\section{Economic Effects}

Substitution of SF for MR not only changed the type of feeds purchased, but also reduced energy costs, because less water had to be heated for MR. In total, feed-related costs decreased by $€ 0.68$ when $1.43 \mathrm{~kg}$ of DM C80 substituted for $1 \mathrm{~kg}$ of DM MR and decreased by $€ 0.71$ when $1.61 \mathrm{~kg}$ of DM C50 substituted for $1 \mathrm{~kg}$ of DM MR (Table 2). These results showed that lower prices per kilogram of product of SF compared with MR (Table 1) more than compensated for the increased DMI. Net result on costs implied an increase of $€ 0.03$ when C80 substituted for $1 \mathrm{~kg}$ of DM MR and equal costs (€0.00) when C50 substituted for $1 \mathrm{~kg}$ of DM $\mathrm{MR}$, if a penalty for higher color scores $(€ 0.71)$ was taken into account (Table 2). This penalty needs to be taken into account to the extent substituting SF

Table 1. Analyzed DM content, estimated gross energy (GE) content, and price for milk replacer (MR), concentrate feed, corn silage, and wheat straw

\begin{tabular}{lcccc}
\hline Item & MR $^{1}$ & Concentrate $^{2}$ & Corn silage & \multirow{2}{*}{ Straw } \\
\hline $\mathrm{DM}(\mathrm{g} / \mathrm{kg}$ of product $)$ & 969.5 & 898 & 297 & 931 \\
GE $(\mathrm{MJ} / \mathrm{kg}$ of DM) & $20.1^{3}$ & $18.45^{4}$ & $18.7^{5}$ & $18.0^{5}$ \\
Price $^{6}(€ / \mathrm{kg}$ of product $)$ & 1.15 & 0.375 & 0.05 & 0.26 \\
\hline
\end{tabular}

${ }^{1}$ Milk replacer composition used in calculations: $37.2 \%$ whey powder, $20.0 \%$ whey protein concentrate, $16.3 \%$ palm oil, $13.9 \%$ delactosed whey, $4.1 \%$ coconut oil, $3.9 \%$ wheat protein isolate, $2.6 \%$ soy protein concentrate, $2.1 \%$ pregelatinized wheat starch.

${ }^{2}$ Concentrate composition used in calculations: $36.2 \%$ corn, $20.6 \%$ lupins, $20.3 \%$ barley, $12.5 \%$ carob meal, $4.4 \%$ corn gluten meal, $6.0 \%$ premix.

${ }^{3}$ Calculated based on GE content of individual nutrients (23.7 MJ $/ \mathrm{kg}$ of CP, $39.6 \mathrm{MJ} / \mathrm{kg}$ of crude fat, $17.5 \mathrm{MJ} /$ $\mathrm{kg}$ of starch, and $15.8 \mathrm{MJ} / \mathrm{kg}$ of lactose).

${ }^{4}$ IPCC (2006).

${ }^{5}$ Berends et al. (2012a).

${ }^{6} \mathrm{KWIN}-\mathrm{V}$ (2013). 
Table 2. Costs (in $€$ ) when $1.43 \mathrm{~kg}$ of DM C80 or $1.61 \mathrm{~kg}$ of DM C50 substituted for $1 \mathrm{~kg}$ of DM milk replacer (MR), while maintaining equal rates of carcass gain ${ }^{1}$

\begin{tabular}{lrr}
\hline Item & C80 & \multicolumn{1}{c}{ C50 } \\
\hline Feed components & -1.19 & -1.19 \\
MR & 0.48 & 0.34 \\
Concentrates & 0.02 & 0.07 \\
Corn silage & 0.04 & 0.11 \\
Straw & -0.04 & -0.04 \\
Water heating & -0.68 & -0.71 \\
Total feed-related costs & 0.71 & 0.71 \\
Penalty for carcass color & 0.03 & 0.00 \\
Net result on costs &
\end{tabular}

${ }^{1} \mathrm{C} 80=80 \%$ concentrates, $10 \%$ corn silage, and $10 \%$ straw on $\mathrm{DM}$ basis; $\mathrm{C} 50=50 \%$ concentrates, $25 \%$ corn silage, and $25 \%$ straw on DM basis.

for MR increases average color scores above 4.8. Color scores increased to this level only at the highest level of SF (Berends et al., 2014).

\section{Environmental Effects}

The net result on GHG emissions when substituting $\mathrm{SF}$ for MR, while maintaining equal rates of carcass gain, was $+0.04 \mathrm{~kg} \mathrm{CO}_{2}$-eq when $1.43 \mathrm{~kg}$ of $\mathrm{DM} \mathrm{C} 80$ substituted for $1 \mathrm{~kg}$ of DM MR and $-0.07 \mathrm{~kg} \mathrm{CO}_{2}$-eq when $1.61 \mathrm{~kg}$ of DM C50 substituted for $1 \mathrm{~kg}$ of DM MR (Table 3). In general, increased $\mathrm{CH}_{4}$ emission from enteric fermentation was compensated for by lower emissions from feed production and lower energy use because of less water to be heated. The increase of $\mathrm{CH}_{4}$ emission from enteric fermentation was less (0.41 $\mathrm{kg} \mathrm{CO}_{2}$-eq) when $\mathrm{SF}$ with high levels of concentrates (C80) substituted for $1 \mathrm{~kg}$ of DM MR, than when SF with more roughage (C50) substituted for $1 \mathrm{~kg}$ of DM $\mathrm{MR}$ (0.61 kg $\mathrm{CO}_{2}$-eq). This difference, however, was compensated for by the difference in reduction of GHG
Table 3. Greenhouse gas emissions (in $\mathrm{kg} \mathrm{CO}_{2}$-equivalents) when 1.43 $\mathrm{kg}$ of DM C80 or $1.61 \mathrm{~kg}$ of DM C50 substituted for $1 \mathrm{~kg}$ of DM milk replacer $(\mathrm{MR})$, while maintaining equal rates of carcass gain ${ }^{1}$

\begin{tabular}{lrr}
\hline Item & C80 & \multicolumn{1}{c}{ C50 } \\
\hline Feed component & -1.45 & -1.45 \\
MR & 1.19 & 0.84 \\
Concentrates & 0.03 & 0.07 \\
Corn silage & 0.00 & 0.00 \\
Straw & -0.14 & -0.14 \\
Water heating & -0.37 & -0.68 \\
Net result feed & -0.03 & -0.03 \\
Enteric fermentation (EF) & 0.28 & 0.20 \\
MR & 0.08 & 0.22 \\
Concentrates & 0.08 & 0.21 \\
Corn silage & 0.41 & 0.61 \\
Straw & 0.04 & -0.07 \\
Net result EF &
\end{tabular}

${ }^{1} \mathrm{C} 80=80 \%$ concentrates, $10 \%$ corn silage, and $10 \%$ straw on DM basis; $\mathrm{C} 50=50 \%$ concentrates, $25 \%$ corn silage, and $25 \%$ straw on DM basis.

emissions associated with feed production, which was lower $\left(0.37 \mathrm{~kg} \mathrm{CO}_{2}\right.$-eq) when $\mathrm{SF}$ with high levels of concentrates (C80) substituted for $1 \mathrm{~kg}$ of DM MR than when SF with more roughage (C50) substituted for 1 $\mathrm{kg}$ of DM MR (0.68 $\mathrm{kg} \mathrm{CO}$-eq).

When each $\mathrm{SF}$ was assigned the same emission factor (5.5\% of GE), the increase of enteric $\mathrm{CH}_{4}$ emission was higher than with the default emission factors (Table 4, SF-MR). With the SF-MR emission factors, the increased enteric $\mathrm{CH}_{4}$ emission could not be compensated for, especially when feeding high levels of concentrates, which now was assigned a higher enteric $\mathrm{CH}_{4}$ emission factor (5.5\% of GE instead of 3.0\%). When C80 substituted for $1 \mathrm{~kg}$ of DM MR, this resulted in an increased overall GHG emissions of $0.25 \mathrm{~kg} \mathrm{CO}_{2}$-eq.

Land occupation associated with feeding SF needed to substitute for $1 \mathrm{~kg}$ of DM MR was higher than land

Table 4. Greenhouse gas emissions (in $\mathrm{kg}$ of $\mathrm{CO}_{2}$-equivalents), calculated using different emission factors for each of three diet components (default), or distinguishing only solid feed and milk replacer (SF-MR), when $1.43 \mathrm{~kg}$ of DM C80 or $1.61 \mathrm{~kg}$ of DM C50 substituted for $1 \mathrm{~kg}$ of DM milk replacer (MR), while maintaining equal rates of carcass gain ${ }^{1}$

\begin{tabular}{|c|c|c|c|c|}
\hline \multirow[b]{2}{*}{ Item } & \multicolumn{2}{|c|}{$\mathrm{C} 80$} & \multicolumn{2}{|c|}{ C50 } \\
\hline & Default & SF-MR & Default & SF-MR \\
\hline \multicolumn{5}{|l|}{ Enteric fermentation } \\
\hline $\mathrm{MR}$ & -0.03 & -0.03 & -0.03 & -0.03 \\
\hline Concentrates & 0.28 & 0.52 & 0.20 & 0.37 \\
\hline Corn silage & 0.08 & 0.07 & 0.22 & 0.19 \\
\hline Straw & 0.08 & 0.06 & 0.21 & 0.18 \\
\hline Net result EF & 0.41 & 0.62 & 0.61 & 0.71 \\
\hline Net result feed & -0.37 & -0.37 & -0.68 & -0.68 \\
\hline Net result feed and EF & 0.04 & 0.25 & -0.07 & 0.03 \\
\hline
\end{tabular}

${ }^{1}$ Default $=0.3 \%$ of GE for milk replacer, $3.0 \%$ of GE for concentrate feeds, and $6.5 \%$ of GE for roughages; $\mathrm{SF}-\mathrm{MR}=0.3 \%$ of GE for milk replacer and $5.5 \%$ of GE for all solid feeds; $\mathrm{C} 80=80 \%$ concentrates, $10 \%$ corn silage, and $10 \%$ straw on DM basis; C50 $=50 \%$ concentrates, $25 \%$ corn silage, and $25 \%$ straw on DM basis. 
occupation associated with feeding MR (Table 5). This higher land occupation was mostly because of the high land occupation associated with growing concentrate ingredients, which is reflected in the higher net result on land occupation $\left(1.47 \mathrm{~m}^{2} \cdot \mathrm{yr}\right)$ when $\mathrm{SF}$ with high levels of concentrates (C80) substituted for $1 \mathrm{~kg}$ of DM MR, than when SF with more roughage (C50) substituted for $1 \mathrm{~kg}$ of DM MR $\left(0.44 \mathrm{~m}^{2} \cdot \mathrm{yr}\right)$. The main reason for the high land occupation is that some concentrate ingredients, for example lupins and carob meal, have a relatively high land occupation (Appendix Table A1).

\section{DISCUSSION}

Substitution rates used in this paper were based on the last $17 \mathrm{wk}$ of the fattening period (i.e., 13-29 wk of age) of veal calves (Berends et al., 2014). Their study showed that substitution rates decrease with age, which means less SF is needed to substitute for $1 \mathrm{~kg}$ of DM MR when calves grow older. To grow well on SF, however, calves need to be stimulated early in life to develop a well-functioning rumen (Berends et al., 2012b; Xie et al., 2013). Calves fed MR diet increased intake of SF slowly during the first $12 \mathrm{wk}$. Therefore, the total amount of SF substituted for MR was relatively low in the first $12 \mathrm{wk}$ compared with the whole fattening period. Including this period in the calculations, therefore, would only slightly influence the overall substitution rates. When this early period would have been included in the analysis, economic benefits per kilogram of substituted MR would have been slightly lower, but economic benefits per calf would be higher because of the larger amount of SF substituted for MR. The effect on GHG emissions is difficult to predict, because no data are available on enteric $\mathrm{CH}_{4}$ emissions from young calves. Land occupation, however, is predicted to increase, as more SF is needed to substitute for MR.

Economic results were calculated with and without a penalty for higher color scores. Without a penalty, an economic benefit was achieved, because costs of SF are lower than costs of MR. Substitution of SF for MR, therefore, is profitable when color scores are $\leq 4.8$. This was the case for 3 of 4 levels of SF for C80 and C50 (Berends et al., 2014). Data on carcass color, however, were available for only a limited number of animals and varied within treatments. Information about penalty systems is scarce and could vary between companies and over time. No strong conclusions, therefore, could be drawn about which levels of substitution of SF for MR will result in acceptable color scores. Additional field trials need to be performed to estimate how much SF could be substituted for MR before economic benefits turn into losses due to penalties for carcass color.
Table 5. Land occupation $\left(\mathrm{m}^{2} \cdot \mathrm{yr}\right)$ when $1.43 \mathrm{~kg}$ of DM C 80 or 1.61 $\mathrm{kg}$ of DM C50 substituted for $1 \mathrm{~kg}$ of DM milk replacer (MR), while maintaining equal rates of carcass gain ${ }^{1}$

\begin{tabular}{lcc}
\hline & \multicolumn{2}{c}{ Land occupation } \\
\cline { 2 - 3 } Item & $\mathrm{C} 80$ & $\mathrm{C} 50$ \\
\hline $\mathrm{MR}$ & -2.68 & -2.68 \\
Concentrates & 4.05 & 2.85 \\
Corn silage & 0.10 & 0.27 \\
Straw & 0 & 0 \\
Net result & 1.47 & 0.44 \\
\hline
\end{tabular}

${ }^{1} \mathrm{C} 80=80 \%$ concentrates, $10 \%$ corn silage, and $10 \%$ straw on DM basis; $\mathrm{C} 50=50 \%$ concentrates, $25 \%$ corn silage, and $25 \%$ straw on DM basis.

Increased fixed costs need to be assessed because of changes in technical farm layout, such as larger feeding troughs or specialized machinery, and increased costs for labor, such as those associated with increased frequency of feeding with higher levels of SF. Regarding future developments in practice, feeding increasing levels of SF is expected when prices of MR relative to $\mathrm{SF}$ increase even more. When prices for MR increase, the economic benefit of substituting SF for MR would become larger.

Based on studies in which $\mathrm{CH}_{4}$ emissions were measured (van den Borne et al., 2006; Labussiere et al., 2009; Berends et al., 2012a, and some unpublished data of J. J. G. C. van den Borne, Wageningen University, Wageningen, the Netherlands, personal communication), it was possible to distinguish between MR and SF, but not between concentrates and roughages, because concentrate to roughage ratios were similar. Roughages, however, are known to give higher enteric $\mathrm{CH}_{4}$ emission than concentrates (Tamminga et al., 2007; De Boer et al., 2011). We, therefore, used the IPCC (2006) value for concentrate-fed feed-lot cattle (3.0\% of GE) for concentrates, the IPCC (2006) value for other cattle $(6.5 \%$ of $\mathrm{GE}$ ) for roughages, and the value derived from the experimental data for MR ( $0.3 \%$ of GE) to differentiate emission factors for each diet component. Results of the sensitivity analysis showed the effect of differentiated enteric $\mathrm{CH}_{4}$ emission factors on net results (Table 4). The most commonly used guidelines for GHG inventories, IPCC Tier 2 (IPCC, 2006), do not differentiate between the diet components used in this study as these guidelines have no specific factors for veal calves. Using the general emission factor for other cattle $(6.5 \%$ of GE) for all diet components is unrealistic and would greatly overestimate the reduction of environmental effects for diets lower in MR. Further research is needed to establish differentiated enteric $\mathrm{CH}_{4}$ emission factors or to develop a Tier 3 model for veal calves, just like what is available for dairy cattle (Dijkstra et al., 1992). 
In the LCA, effects of by-products were assessed based on their nutritional value (protein and energy content), when used as ingredients in pig feed. Different methodological choices could have been made, however, which would have resulted in different assessments. We highlight 3 important alternative choices. First, some ingredients used in animal feed, especially ones that are derived from whey, compete primarily with ingredients used in human food. Information on which products compete and on which property to base the substitution was not available. If we assume that whey competes with another highly nutritious food product, this is probably from animal origin. Products from animal origin, in general, have a greater environmental effect than crops such as soy and barley (Nijdam et al., 2012; Meier and Christen, 2013). When a higher effect was allocated to feed ingredients derived from whey, this would have resulted in a reduction of the net environmental effect in this study.

Second, economic allocation could have been used instead of system expansion. This would have led to lower effects for MR, because some by-products are assigned an economic value of zero (Vellinga et al., 2013). Wet whey, for example, has a low value compared with cheese. No effect from the production of milk, therefore, is allocated to wet whey. As a result, the only effect allocated to whey powder is the effect of drying, which is low compared with the economic value of the dried whey products and, therefore, not reasonable. Because more than $70 \%$ of the ingredients of MR were derived from whey, this would have resulted in an increase of the net environmental effect in this study.

Third, allocation based on some physical property could have been used. Flysjö et al. (2014), for example, allocated the effect of milk production based on fat and protein content, which resulted in an effect of 7.4 $\mathrm{kg} \mathrm{CO}_{2}$-eq per $\mathrm{kg}$ for "milk powder and whey based products." This value is about 10 times greater than the effect of whey-based ingredients used in our study. Using this value would result in higher GHG emissions for $\mathrm{MR}$ and a reduction of the net environmental effect in this study. No data for land occupation were available from their study. A higher allocation factor, however, would have led to higher land occupation for $\mathrm{MR}$, and again a reduction of the net environmental effect in this study. In conclusion, the 2 most reasonable alternative allocation methods, system expansion with application in human food and allocation on physical properties, would have yielded a reduction of the net environmental effect in this study when providing more $\mathrm{SF}$ to veal calves.

With increasing excretion of $\mathrm{OM}$ due to a lower digestibility of $\mathrm{SF}$ than of $\mathrm{MR}, \mathrm{CH}_{4}$ emissions could be expected to increase. Available emission factors (Van der Hoek, 2002; IPCC, 2006), however, were not specific enough to model dietary changes regarding $\mathrm{CH}_{4}$ emissions from manure. The $\mathrm{N}_{2} \mathrm{O}$ emission from slurry is generally calculated as $0.1 \%$ of total $\mathrm{N}$ excretion (Oenema et al., 2000). A shift in nitrogen excretion from urine to feces (Berends et al., 2015), therefore, would not affect calculated $\mathrm{N}_{2} \mathrm{O}$ emission. Total $\mathrm{N}$ excretion and, consequently, calculated $\mathrm{N}_{2} \mathrm{O}$ emission, however, could be expected to decrease. Total $\mathrm{N}$ intake decreased with increasing substitution of SF for MR and increasing amount of roughage in SF (210 $\mathrm{g}$ of $\mathrm{CP}$ in $1 \mathrm{~kg}$ of DM MR, $171 \mathrm{~g}$ of CP in $1.43 \mathrm{~kg}$ of DM $\mathrm{C} 80$, and $151 \mathrm{~g}$ of $\mathrm{CP}$ in $1.61 \mathrm{~kg}$ of DM C50), whereas $\mathrm{N}$ retention could be expected to remain equal when maintaining equal rates of carcass gain.

A trade-off seems to emerge with increasing land occupation when increasing levels of SF, especially with high levels of concentrate (C80). This increase in land occupation was mainly caused by low crop yields, of high-protein ingredients of the concentrate feed, namely lupins and carob meal (Appendix Table A1). Technical limitations on feed ingredients, however, are stronger for MR ingredients than for concentrate ingredients because MR has to be dissolved in water. Different protein or nonprotein nitrogen sources have been applied successfully as concentrate ingredient, such as extruded soybeans (Prevedello et al., 2012), or extruded peas or urea (Brscic et al., 2014). More options for SF than MR are available, therefore, to look for alternative high-protein ingredients, which could reduce land occupation.

\section{CONCLUSIONS}

When considering feeding costs and revenues from meat, substituting SF for part of the MR in diets of veal calves is economically attractive, provided that the meat can be sold at the same price. When carcass color scores become too high, however, lower feeding costs are offset by lower revenues from meat. Land occupation for the production of feed ingredients increases, whereas with respect to GHG emissions, a shift occurs from emissions related to the production of feed ingredients to emissions related to enteric $\mathrm{CH}_{4}$. The net effect on GHG emissions, however, is close to neutral.

\section{ACKNOWLEDGMENTS}

The authors thank the Dutch Ministry of Economic Affairs, the Netherlands Organisation for Scientific Research (NWO, The Hague, the Netherlands), and the Product Board Animal Feed (The Hague, the Netherlands) for financially supporting this research. Furthermore, we thank all who contributed to the setup and execution of the experiment, especially Eddie Bok- 
kers (Animal Production Systems group, Wageningen University, Wageningen, the Netherlands) and Kees van Reenen (Wageningen UR Livestock Research, Wageningen, the Netherlands). Finally, we thank two anonymous reviewers for their valuable comments, and Michael Grossman (Department of Animal Sciences, University of Illinois, Urbana) for editing the paper.

\section{REFERENCES}

Baumann, H., and A. Tillman. 2004. The Hitch Hiker's Guide to LCA. An orientation in life cycle assessment methodology and application. Studentlitteratur, Lund, Sweden.

Beauchemin, K. A., and S. M. McGinn. 2005. Methane emissions from feedlot cattle fed barley or corn diets. J. Anim. Sci. 83:653-661.

Berends, H., J. J. G. C. van den Borne, S. J. J. Alferink, C. G. Van Reenen, E. A. M. Bokkers, and W. J. J. Gerrits. 2012a. Lowprotein solid feed improves the utilization of milk replacer for protein gain in veal calves. J. Dairy Sci. 95:6654-6664. http://dx.doi. org/10.3168/jds.2012-5463.

Berends, H., J. J. G. C. van den Borne, H. Mollenhorst, C. G. Van Reenen, E. A. M. Bokkers, and W. J. J. Gerrits. 2014. Utilization of roughages and concentrates relative to that of milk replacer increases strongly with age in veal calves. J. Dairy Sci. 97:6475-6484. http://dx.doi.org/10.3168/jds.2014-8098.

Berends, H., J. J. G. C. van den Borne, B. A. Røjen, W. H. Hendriks, and W. J. J. Gerrits. 2015. Effect of protein provision via milk replacer or solid feed on protein metabolism in veal calves. J. Dairy Sci. 98:1119-1126. http://dx.doi.org/10.3168/jds.2014-8375.

Berends, H., C. G. Van Reenen, N. Stockhofe-Zurwieden, and W. J. J. Gerrits. 2012b. Effects of early rumen development and solid feed composition on growth performance and abomasal health in veal calves. J. Dairy Sci. 95:3190-3199. http://dx.doi.org/10.3168/ jds.2011-4643.

Brscic, M., P. Prevedello, A. L. Stefani, G. Cozzi, and F. Gottardo. 2014. Effects of the provision of solid feeds enriched with protein or nonprotein nitrogen on veal calf growth, welfare, and slaughter performance. J. Dairy Sci. 97:4649-4657. http://dx.doi. org/10.3168/jds.2013-7618.

Church, D. C. 1988. The Ruminant Animal: Digestive Physiology and Nutrition. Prentice Hall, Englewood Cliffs, NJ.

Cozzi, G., M. Brscic, and F. Gottardo. 2009. Main critical factors affecting the welfare of beef cattle and veal calves raised under intensive rearing systems in Italy: A review. Ital. J. Anim. Sci. 8(SUPPL. 1):67-80. http://dx.doi.org/10.4081/ijas.2009.s1.67.

Cozzi, G., F. Gottardo, S. Mattiello, E. Canali, E. Scanziani, M. Verga, and I. Andrighetto. 2002. The provision of solid feeds to veal calves: I. Growth performance, forestomach development, and carcass and meat quality. J. Anim. Sci. 80:357-366.

CVB. 2011. CVB Veevoedertabel 2011-Chemische samenstellingen en nutritionele waarden van voedermiddelen (CVB Feed Table 2011). Productschap Diervoeder (Product Board Animal Nutrition), The Hague, the Netherlands.

Dalgaard, R., J. Schmidt, N. Halberg, P. Christensen, M. Thrane, and W. A. Pengue. 2008. LCA of soybean meal. Int. J. Life Cycle Assess. 13:240-254. http://dx.doi.org/10.1065/lca2007.06.342.

De Boer, I. J. M., C. Cederberg, S. Eady, S. Gollnow, T. Kristensen, M. Macleod, M. Meul, T. Nemecek, L. T. Phong, G. Thoma, H. M. G. Van der Werf, A. G. Williams, and M. A. Zonderland-Thomassen. 2011. Greenhouse gas mitigation in animal production: Towards an integrated life cycle sustainability assessment. Curr. Opin. Environ. Sustain. 3:423-431. http://dx.doi.org/10.1016/j. cosust.2011.08.007.

De Vries, M., and I. J. M. De Boer. 2010. Comparing environmental effects for livestock products: A review of life cycle assessments. Livest. Sci. 128:1-11. http://dx.doi.org/10.1016/j.livsci.2009.11.007.
Dijkstra, J., H. D. S. C. Neal, D. E. Beever, and J. France. 1992. Simulation of nutrient digestion, absorption and outflow in the rumen: Model description. J. Nutr. 122:2239-2256.

Flatt, W. P., R. G. Warner, and J. K. Loosli. 1958. Influence of purified materials on the development of the ruminant stomach. J. Dairy Sci. 41:1593-1600. http://dx.doi.org/10.3168/jds.S00220302(58)91138-X

Flysjö, A., M. Thrane, and J. E. Hermansen. 2014. Method to assess the carbon footprint at product level in the dairy industry. Int Dairy J. 34:86-92. http://dx.doi.org/10.1016/j.idairyj.2013.07.016.

Forster, P., V. Ramaswamy, P. Artaxo, T. Berntsen, R. Betts, D. W. Fahey, J. Haywood, J. Lean, D. C. Lowe, G. Myhre, J. Nganga, R. Prinn, G. Raga, M. Schulz, and R. Van Dorland. 2007. Changes in Atmospheric Constituents and in Radiative Forcing. Climate Change 2007: The Physical Science Basis. Cambridge University Press, Cambridge, United Kingdom, and New York, NY.

Gerber, P. J., H. Steinfeld, B. Henderson, A. Mottet, C. Opio, J. Dijkman, A. Falcucci, and G. Tempio. 2013. Tackling climate change through livestock-A global assessment of emissions and mitigation opportunities. Food and Agriculture Organization of the United Nations (FAO), Rome, Italy.

Guinée, J. B., M. Gorrée, R. Heijungs, G. Huppes, R. Kleijn, A. De Koning, L. Van Oers, A. Wegener Sleeswijk, S. Suh, H. A. Udo de Haes, H. De Bruijn, R. Van Duin, and M. A. J. Huijbregts. 2002. Handbook on life cycle assessment. Operational guide to the ISO standards. Kluwer Academic Publishers, Dordrecht, the Netherlands.

IPCC. 2006. Intergovernmental Panel on Climate Change. Guidelines for National Greenhouse Gas Inventories. Volume 4: Agriculture, forestry and other land use. Prepared by the National Greenhouse Gas Inventories Program. H. S. Eggleston, L. Buendia, K. Miwa, T. Ngara, and K. Tanabe, ed. IGES, Hayama, Japan.

Kay, R. D., W. M. Edwards, and P. A. Duffy. 2011. Farm Management. 7th ed. McGraw-Hill, New York, NY.

KWIN-V. 2013. Kwantitatieve Informatie Veehouderij 2013-2014 (Quantitative Information Livestock 2013-2014). Wageningen UR Livestock Research, Lelystad, the Netherlands.

Labussiere, E., S. Dubois, J. Van Milgen, G. Bertrand, and J. Noblet. 2009. Effect of solid feed on energy and protein utilization in milk-fed veal calves. J. Anim. Sci. 87:1106-1119. http://dx.doi. org/10.2527/jas.008-1318.

LEI. 2014. Price Information Desk; Wheypowder. LEI Wageningen UR, The Hague, the Netherlands. Accessed Jan. 6, 2016. http:// www3.lei.wur.nl/prijzenpopup/default.aspx?lang $=0$.

Leruste, H., M. Brscic, G. Cozzi, B. Kemp, M. Wolthuis-Fillerup, B. J. Lensink, E. A. M. Bokkers, and C. G. van Reenen. 2014. Prevalence and potential influencing factors of non-nutritive oral behaviors of veal calves on commercial farms. J. Dairy Sci. 97:7021-7030. http://dx.doi.org/10.3168/jds.2014-7917.

Mattiello, S., E. Canali, V. Ferrante, M. Caniatti, F. Gottardo, G. Cozzi, I. Andrighetto, and M. Verga. 2002. The provision of solid feeds to veal calves: II. Behaviour, physiology, and abomasal damage. J. Anim. Sci. 80:367-375.

Meier, T., and O. Christen. 2013. Environmental effects of dietary recommendations and dietary styles: Germany as an example. Environ. Sci. Technol. 47:877-888. http://dx.doi.org/10.1021/ es302152v.

Nijdam, D., T. Rood, and H. Westhoek. 2012. The price of protein: Review of land use and carbon footprints from life cycle assessments of animal food products and their substitutes. Food Policy 37:760-770. http://dx.doi.org/10.1016/j.foodpol.2012.08.002.

Oenema, O., G. L. Velthof, N. Verdoes, P. W. G. Groot Koerkamp, A. Bannink, H. G. Van der Meer, and K. W. Van der Hoek. 2000. Forfaitaire waarden voor gasvormige stikstofverliezen uit stallen en mestopslagen. Alterra-rapport 107. Alterra, Research Instituut voor de Groene Ruimte, Wageningen, the Netherlands.

Prevedello, P., M. Brscic, E. Schiavon, G. Cozzi, and F. Gottardo. 2012. Effects of the provision of large amounts of solid feeds to veal calves on growth and slaughter performance and intravitam and postmortem welfare indicators. J. Anim. Sci. 90:3538-3546. 
Steinfeld, H., P. Gerber, T. Wassenaar, V. Castel, M. Rosales, and C. De Haan. 2006. Livestock's long shadow: Environmental issues and options. Food and Agriculture Organization of the United Nations (FAO), Rome, Italy.

Suárez, B. J., C. G. Van Reenen, W. J. J. Gerrits, N. Stockhofe, A. M. Van Vuuren, and J. Dijkstra. 2006. Effects of supplementing concentrates differing in carbohydrate composition in veal calf diets: II. Rumen development. J. Dairy Sci. 89:4376-4386. http://dx.doi. org/10.3168/jds.S0022-0302(06)72484-5.

Suárez, B. J., C. G. Van Reenen, N. Stockhofe, J. Dijkstra, and W. J. J. Gerrits. 2007. Effect of roughage source and roughage to concentrate ratio on animal performance and rumen development in veal calves. J. Dairy Sci. 90:2390-2403. http://dx.doi.org/10.3168/ jds.2006-524.

Tamminga, S. A., A. Bannink, J. Dijkstra, and R. Zom. 2007. Feeding strategies to reduce methane loss in cattle. Report 34. Animal Sciences Group, Wageningen UR, Lelystad, the Netherlands.

Van den Borne, J. J. G. C., M. W. A. Verstegen, S. J. J. Alferink, R. M. M. Giebels, and W. J. J. Gerrits. 2006. Effects of feeding frequency and feeding level on nutrient utilization in heavy preruminant calves. J. Dairy Sci. 89:3578-3586. http://dx.doi. org/10.3168/jds.S0022-0302(06)72397-9.

Van der Hoek, K. W. 2002. Uitgangspunten voor de mest- en ammoniakberekeningen 1999 tot en met 2001 zoals gebruikt in de Milieubalans 2001 en 2002, inclusief dataset landbouwemissies 1980 - 2001 (Input variables for manure and ammonia data in the Environmental Balance 2001 and 2002 including dataset agricultural emissions 1980-2001). RIVM rapport 773004013. RIVM, Bilthoven, the Netherlands.

Van Middelaar, C. E., P. B. M. Berentsen, J. Dijkstra, and I. J. M. De Boer. 2013. Evaluation of a feeding strategy to reduce greenhouse gas emissions from dairy farming: The level of analysis matters. Agric. Syst. 121:9-22. http://dx.doi.org/10.1016/j.agsy.2013.05.009.

Van Zanten, H. H. E., H. Mollenhorst, J. W. De Vries, C. E. Van Middelaar, H. R. J. Van Kernebeek, and I. J. M. De Boer. 2014.
Assessing environmental consequences of using co-products in animal feed. Int. J. Life Cycle Assess. 19:79-88. http://dx.doi. org/10.1007/s11367-013-0633-x.

Veissier, I., A. R. Ramirez de la Fe, and P. Pradel. 1998. Nonnutritive oral activities and stress responses of veal calves in relation to feeding and housing conditions. Appl. Anim. Behav. Sci. 57:35-49. http://dx.doi.org/10.1016/S0168-1591(97)00108-1.

Vellinga, T. V., H. Blonk, M. Marinussen, W. J. Van Zeist, I. J. M. De Boer, and D. Starmans. 2013. Methodology used in feedprint: A tool quantifying greenhouse gas emissions of feed production and utilization. Report 674. Wageningen UR Livestock Research, Lelystad, the Netherlands.

Webb, L. E., E. A. M. Bokkers, B. Engel, W. J. J. Gerrits, H. Berends, and C. G. van Reenen. 2012. Behaviour and welfare of veal calves fed different amounts of solid feed supplemented to a milk replacer ration adjusted for similar growth. Appl. Anim. Behav. Sci 136:108-116. http://dx.doi.org/10.1016/j.applanim.2011.12.004.

Webb, L. E., B. Engel, H. Berends, C. G. Van Reenen, W. J. J. Gerrits, I. J. M. De Boer, and E. A. M. Bokkers. 2014. What do calves choose to eat and how do preferences affect behaviour? Appl. Anim. Behav. Sci. http://dx.doi.org/10.1016/j.applanim.2014.09.016.

Weidema, B. P. 2003. Market information in life cycle assessment. Environmental Project No. 863. Danish Ministry of the Environment, Environmental Protection Agency. Accessed Sep. 30, 2014. http:// www.norlca.org/resources/780.pdf

Weidema, B. P., C. Bauer, R. Hischier, C. Mutel, T. Nemecek, J. Reinhard, C. O. Vadenbo, and G. Wernet. 2013. The ecoinvent database: Overview and methodology, Data quality guideline for the ecoinvent database version 3. Accessed Jan. 3, 2016. www. ecoinvent.org

Xie, X. X., Q. X. Meng, P. Liu, H. Wu, S. R. Li, L. P. Ren, and X. Z. Li. 2013. Effects of a mixture of steam-flaked corn and extruded soybeans on performance, ruminal development, ruminal fermentation, and intestinal absorptive capability in veal calves. J. Anim. Sci. 91:4315-4321.

\section{APPENDIX}

Table A1. Main products, their by-products, if applicable, and greenhouse gas (GHG) emission and land occupation (LO) per kilogram of product

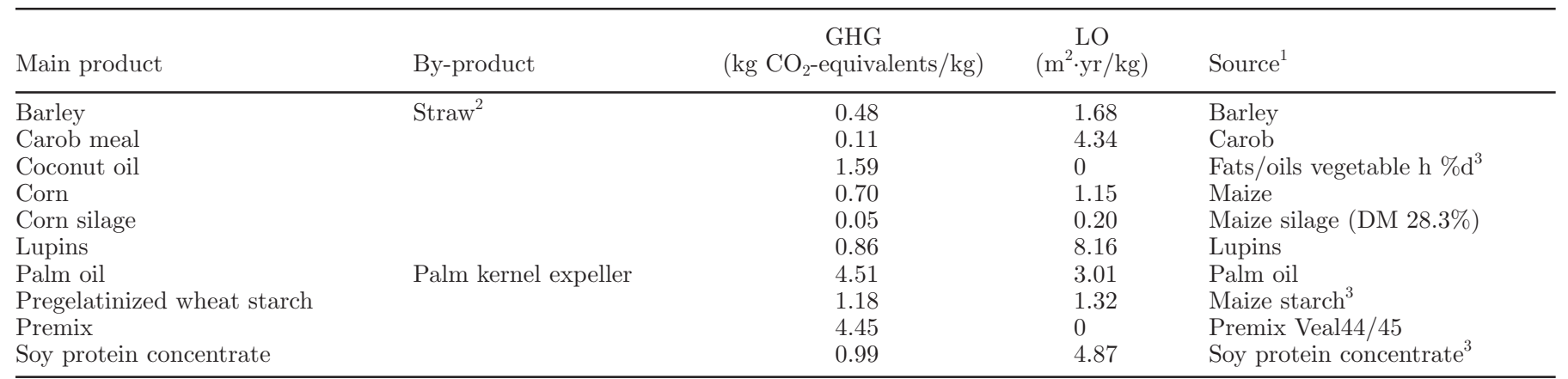

${ }^{1}$ Name of product used in Vellinga et al. (2013).

${ }^{2}$ Zero effect for straw was assumed.

${ }^{3}$ Economically allocated effect as reported in Vellinga et al. (2013). 
Table A2. By-products, their net energy and digestible protein contents, and the corresponding amounts of soybean meal and barley substituted in pig feed

\begin{tabular}{|c|c|c|c|c|}
\hline By-product & $\begin{array}{c}\text { Net energy }{ }^{1} \\
\text { (MJ/kg of product) }\end{array}$ & $\begin{array}{l}\text { Digestible protein } \\
\text { (kg/kg of product) }\end{array}$ & $\begin{array}{c}\text { Soybean meal } \\
\text { (kg/kg of product) }\end{array}$ & $\begin{array}{c}\text { Barley } \\
(\mathrm{kg} / \mathrm{kg} \text { of product })\end{array}$ \\
\hline Corn gluten meal & 10.42 & 0.567 & 1.24 & 0.01 \\
\hline Delactosed whey powder & 10.02 & 0.229 & 0.38 & 0.75 \\
\hline Palm kernel expeller & 8.30 & 0.090 & 0.06 & 0.85 \\
\hline Wheat protein isolate & 10.34 & 0.744 & 1.69 & -0.41 \\
\hline Whey powder & 10.62 & 0.104 & 0.04 & 1.11 \\
\hline Whey protein conc. ${ }^{3}$ & 10.38 & 0.316 & 0.59 & 0.59 \\
\hline
\end{tabular}

${ }^{1}$ Net energy value in pig feed (CVB, 2011).

${ }^{2}$ Digestible protein value in pig feed (CVB, 2011).

${ }^{3}$ Whey protein concentrate: CP content $35 \%$ on DM basis, assumed DM content $96 \%$. Net energy value and protein digestibility not available, so taken from skim milk powder.

Table A3. Net energy and digestible protein contents (CVB, 2011) and environmental effect values used for soybean meal and barley per kilogram of product used to calculate substitution of feed energy and protein

\begin{tabular}{lccccc}
\hline Product & $\begin{array}{c}\text { Net energy }^{1} \\
(\mathrm{MJ} / \mathrm{kg})\end{array}$ & $\begin{array}{c}\text { Digestible protein }^{2} \\
(\mathrm{~kg} / \mathrm{kg})\end{array}$ & $\begin{array}{c}\mathrm{GHG} \\
\left.(\mathrm{kg} \mathrm{CO})^{-}-\mathrm{eq} / \mathrm{kg}\right)\end{array}$ & $\begin{array}{c}\mathrm{LU} \\
\left(\mathrm{m}^{2} / \mathrm{kg}\right)\end{array}$ & Source \\
\hline Soybean meal & 8.32 & 0.458 & 0.72 & 3.60 & Dalgaard et al., 2008 $^{3}$ \\
Barley & 9.21 & 0.076 & 0.49 & 1.68 & FeedPrint $^{4}$ \\
\hline
\end{tabular}

${ }^{1}$ Net energy value in pig feed (CVB, 2011).

${ }^{2}$ Digestible protein value in pig feed (CVB, 2011).

${ }^{3}$ Soybean meal with palm oil as marginal oil.

${ }^{4}$ Data from FeedPrint (Vellinga et al., 2013) were recalculated to avoid allocation of part of the effect to straw. No substitution of straw was assumed. 